\title{
Parental Anxiety and Its Relationship with Headache in Children
}

\author{
Ebeveyn Anksiyetesi ve Çocuklarda Baş Ağrısı ile İlişkisi
}

\section{${ }^{1}$ Cagla Ozdemir, ${ }^{2}$ Cuneyt Karagol, ${ }^{3}$ Ibrahim Halil Oncel , ${ }^{4}$ Zeynep Selen Karalok, ${ }^{5}$ Ali Gungor , ${ }^{6}$ Gulser Dinc,${ }^{7}$ Cenk Aypak}

${ }^{1}$ Kutahya Provincial Health Directorate, Kutahya, Turkey

${ }^{2}$ Department of Pediatric Rheumatology, Ankara City Hospital, Ankara, Turkey

${ }^{3}$ Department of Pediatric Neurology, Hacettepe University Faculty of Medicine, Ankara, Turkey

${ }^{4}$ Department of Pediatric Neurology, Akdeniz University Faculty of Medicine, Ankara, Turkey

${ }^{5}$ Department of Pediatric Emergency Medicine, Dr. Sami Ulus Maternity and Child Health and Diseases Training and Research Hospital, Ankara, Turkey

${ }^{6}$ Department of Child and Adolescent Psychiatry, Ankara City Hospital, Ankara, Turkey

${ }^{7}$ Department of Family Medicine, Ankara Dışkapı Yıldırım Beyazıt Training and Research Hospital, Ankara, Turkey

\section{Correspondence:} Çağla ÖZDEMİR

Kutahya Provincial Health Directorate, Kutahya, Turkey e-mail: cagla_gocen06@yahoo.com.tr

\section{Abstract}

We aimed to evaluate the anxiety levels of parents of patients visit to pediatric neurology outpatient clinics due to headaches. Methods: An analytical cross-sectional study was performed involving 154 participants. Participants were divided into a headache group $(\mathrm{n}=80)$ and a control group $(\mathrm{n}=74)$. The State Trait Anxiety Inventory (STAI) and Family Assessment Scale were used to assess parents' anxiety levels. The mean age of the headache group was $13.4 \pm 2.7$ years, and the mean age of the control group was $12.2 \pm 3.3$ years. Females were more common in the headache group compared to the control group $(\mathrm{p}=0.017)$. There were significant differences in the socio-demographic characteristics between the groups. For the headache group, the family assessment scale total score $(\mathrm{p}=0.046)$ from the family assessment scale sub-scores, the behavior control $(\mathrm{p}=0.020)$, and the general functions $(\mathrm{p}=$ $0.034)$ sub-scores were significantly higher than the control group. However, no significant differences were noted with respect to problem solving $(\mathrm{p}=0.168)$, communication $(\mathrm{p}=0.520)$, roles $(0.082)$, emotional reactions $(\mathrm{p}=0.654)$ and showing the required attention level $(\mathrm{p}=0.943)$ scores using the STAI I-II $(\mathrm{p}=0.509 / \mathrm{p}=0.542)$. Moreover, the Family Evaluation Scale subscales did not differ significantly between the groups. Childhood headaches can be an indicator of domestic pathology. Accordingly, when considering psychological factors, children with headaches should be evaluated together with familial factors, including physical examinations, laboratory, and imaging studies

Keywords: Child, consultation, inpatient, neurology

Çalışmada baş ağrısı nedeni ile çocuk nöroloji polikliniklerine başvuran hastaların ebeveynlerinin anksiyete düzeyleri ve bunu etkileyen faktörlerin değerlendirilmesi amaçlanmıştır. Analitik kesitsel bir çalışma gerçekleştirildi. Çalışmaya 154 hasta dahil edildi: Baş ağrısı grubu ( $\mathrm{n}=80)$, kontrol grubu $(\mathrm{n}=74)$. Dahil edilme ve dışlanma kriterlerini karşılayan 7-17 yaş arasındaki hastaların ebeveynlerine, ebeveyn anksiyetesinin değerlendirildiği Durumluk-Sürekli Kaygı Envanteri’nin (State Trait Anxiety Inventory-STAI) ve Aile Değerlendirme Ölçeği yapıldı. Hastaların sosyodemografik verileri ve baş ağrısı özellikleri kaydedildi. Baş ağrısı grubunun yaş ortalaması 13,4 $\pm 2,7$ yıl, kontrol grubunun yaş ortalaması 12,2 $\pm 3,3$ yıldı. Baş ağrısı grubunda kız cinsiyet daha sıktı (\%75 \& \%56,8, p=0,017). Sosyo-demografik özellikler gruplar arasında anlamlı farklılık gösteriyordu. Bas ağrısı olanlarda aile değerlendirme ölçeği total skoru $(p=0,046)$, aile değerlendirme ölçeği alt-skorları arasından, davranış kontrolü $(p=0,020)$ ve genel işlevler $(\mathrm{p}=0,034)$ alt skorları kontrol grubuna göre anlamlı derecede daha yüksek saptandı. Bununla birlikte STAI I-II ( $\mathrm{p=0,509/}$ $\mathrm{p}=0,542)$ ve Aile Değerlendirme Ölçeği alt skorlarından problem çözme $(\mathrm{p}=0,168)$, iletişim ( $\mathrm{p}=0,520)$, roller $(0,082)$, duygusal tepki verebilme $(p=0,654)$ ve gereken ilgiyi gösterme $(p=0,943)$ skorları, gruplar arasında anlamlı farklılık göstermedi. Çocukluk çağı baş ağrıları aile içi patolojinin de bir göstergesi olabileceği için; psikolojik etmenler de göz önünde bulundurularak baş ağrısı olan çocuklar fizik muayene, laboratuvar ve görüntüleme incelemelerinin yanında ailesel etmenler ile beraber değerlendirilmelidir.

Anahtar Kelimeler: Çocuk, Baş Ağrısı, Ebeveyn Anksiyetesi, Aile Fonksiyonelliği 


\section{Introduction}

Headaches are among the most common neurological symptoms in children and adolescents. Studies have indicated that between $50-80 \%$ of individuals aged between 7 and 15 years suffer from headaches and that its prevalence increases with age. The resultant restrictions in the daily life activities of the child include school absenteeism, learning difficulties, and a significant socioeconomic burden on families $(1,2)$.

Psychological factors play an important role in childhood headaches. Furthermore, childhood headaches pose a higher risk of the individual developing chronic headaches in adulthood. Psychiatric comorbidity also increases this chronicization. Chronic pain can be associated with anxiety, depression, or behavioral problems and can affect a child's appetite, sleep, and social activities. Collectively, school absenteeism and their inadequate participation in activities causes a decrease in a child's quality of life and results in both the family and the childrenbecoming less efficient (3-5).

The literature only encompasses a few studies on childhood headaches and comorbid psychopathology or domestic psychopathology. In this study, we aimed to establish the level of anxiety and perceptions in the families of children with headaches.

\section{Materials and Methods}

The study employed an analytical crosssectional design. It was conducted between May 2019 and December 2019 and included 154 participants aged between 7 and 17 years. The case group consisted of 80 patients who had applied to the general pediatric outpatient clinic of our hospital complaining of headaches. These patients were subsequently referred to the pediatric neurology outpatients' clinic. The remaining 74 participants constituted the control group. These participants had also applied to the general pediatric outpatient clinics for any reason other than a chronic disease.

Inclusion criteria were; parents whose child is over seven years of age, applying to a general pediatric or pediatric neurology outpatients clinic for the first time with a headache complaint. Exclusion criterias were: parents under the age of 18, having repeated applications to the outpatients' clinic with a headache complaint, lack of sociocultural level preventing them from comprehending the directed questionnaires and scales.

The age, education level, and socioeconomic status of all participants and their parents were recorded. The questionnaire included questions on the child's headache duration, frequency, localization, accompanying symptoms (nausea, vomiting, abdominal pain, fever, visual impairment) and any resultant restrictions in life activities. The questions also examined the patients' family histories. The State Trait Anxiety Inventory (STAI) was used to evaluate anxiety levels of parents and the Family Assessment Scale (FAS) was used to assess functionality and general condition of family. The FAS was performed using face-to-face interviews.

Once all participants were informed of all aspects of the study, voluntary consent was obtained from the families for participation in the study, and the study was approved by the local ethics committee (approval no: 2019101) and Institutional review board.

\section{Assessment Methods}

\section{STAI}

The STAI was developed by Spielberger et al. in 1970 , to discern the state and trait anxiety levels of individuals (6). Subsequently, Öner and Le Compte performed the translation of the STAI into Turkish and assessed its validity and reliability (7). The scale is based on a self-reporting methodology and is divided into 40 items consisting of short statements. The scale is a four-point Likert scale that consists of two sections. Additionally, it also includes a 20-item "state anxiety form" that aims to establish an individual's feeling at the time of performance. It also consists of a 20-item "trait anxiety form" that was created to establish the individual's general feelings. 


\section{Family Assessment Scale}

The FAS developed by Epstein et al. (8) in 1983 helps to enhance understanding of the family's functionality and general condition. FAS has seen wider applicability and is translated into more than 20 languages. FAS evaluates family members' perceptions about their families. The scale includes 60 articles and seven sub-scales: problem solving, communication, roles, emotional response, showing the required attention, behavior control, and general functions. The FAS scale aims to assess whether families can fulfill their functions according to the perceptions of the families. It also establishes in which fields their functions are fulfilled. In Turkey, Bulut established the validity and reliability of the FAS scale in1990 (9).

\section{Statistical Analysis}

Statistical analyses were performed using the SPSS version 21.0 (IBM®, Chicago, USA) package. The suitability of variables to normal distribution was examined using visual (histogram and probability graphs) and analytical methods (Shapiro-Wilk test). Descriptive statistics were presented as the mean and the standard deviation in normally distributed numerical data and as numbers and percentages in nominal data. In the independent groups, the t-test was used for the analysis of normally distributed numerical variables. This involved using the one-way ANOVA test between the three groups and using the t-test in spouses for the within groups analyses. The Mann-Whitney $U$ test was used to perform comparisons between two groups for numerical variables that did not show a normal distribution. Whereas the Kruskal-Wallis test was employed for nonnormal distribution comparisons between three groups. Finally, the chi-square test was used to evaluate nominal data between the two groups. The value of $p<0.05$ was accepted as statistically significant.

\section{Results}

\section{Sociodemographic and clinical features}

The mean age of the headache group was $13.4 \pm 2.7$ years, and the mean age of the control group was $12.2 \pm 3.3$ years. Accordingly, the headache group consisted of older participants compared to the control group $(p=0.022)$. Moreover, a comparison of the two groups identified a higher percentage of females in the headache group $(75 \%)$ compared to the control group (56.8\%) $(\mathrm{p}=$ 0.017). The headaches were significantly more frequent in children of mothers with primary education and below $(\mathrm{p}=0.035)$ and in children from low-income families $(\mathrm{p}=$ 0.016). There were only a few families in both groups that were identified as either separated or divorced. For this reason, they were not included in the analysis. The sociodemographic characteristics of the patients are summarized in Table 1.

Table 1. Sociodemographic characteristics of the patients

\begin{tabular}{|c|c|c|c|c|c|c|}
\hline & & & $\begin{array}{c}\text { Headache } \\
(n=80)\end{array}$ & $\begin{array}{c}\text { Control } \\
(n=74)\end{array}$ & Test & p \\
\hline Age & & Mean \pm SS & $13,4 \pm 2,7$ & $12,2 \pm 3,3$ & $t=2,316$ & 0,022 \\
\hline Parent Age & & & $40,3 \pm 6,0$ & $37,9 \pm 5,9$ & $t=2,112$ & 0,037 \\
\hline \multirow[t]{3}{*}{ Sex } & & N (\%) & & & & \\
\hline & Female & & $60(75)$ & $42(56,8)$ & $X=5,721$ & 0,017 \\
\hline & Male & & $20(25)$ & $32(43,2)$ & & \\
\hline \multirow{3}{*}{$\begin{array}{l}\text { Marital status of the } \\
\text { family }\end{array}$} & & N (\%) & & & & \\
\hline & Together & & $79(98,8)$ & $64(86,5)$ & & \\
\hline & Separate & & $1(1,3)$ & $10(13,5)$ & & \\
\hline \multirow{3}{*}{$\begin{array}{l}\text { Education level of } \\
\text { mother }\end{array}$} & & N (\%) & & & & \\
\hline & $\begin{array}{l}\text { Primary } \\
\text { education } \\
\text { and below }\end{array}$ & & $55(68,8)$ & $38(52,1)$ & $X=4,463$ & 0,046 \\
\hline & $\begin{array}{l}\text { High school } \\
\text { and above }\end{array}$ & & $25(31,3)$ & $35(47,9)$ & & \\
\hline
\end{tabular}




\begin{tabular}{|c|c|c|c|c|c|}
\hline \multicolumn{6}{|c|}{ Education level of } \\
\hline & $\begin{array}{c}\text { Primary } \\
\text { education } \\
\text { and below }\end{array}$ & $39(48,8)$ & $23(31,5)$ & $X=4,709$ & 0,033 \\
\hline & $\begin{array}{l}\text { High school } \\
\text { and above }\end{array}$ & $41(51,3)$ & $50(68,5)$ & & \\
\hline \multicolumn{6}{|c|}{ Income rate } \\
\hline & Low & $46(57,5)$ & $28(37,8)$ & $X=5,954$ & 0,016 \\
\hline & High & $34(42,5)$ & $46(62,2)$ & & \\
\hline
\end{tabular}

Similarly, $55 \%$ of the patients were found to have a family history of headaches. Moreover, headaches were described globally in $37.2 \%$ of patients. $46 \%$ of patients experienced headaches less than three times a week, and the duration of the attack usually lasted between two and four hours in 36\% of patients. The characteristics of the headaches are listed in Table 2.

Table 2. Characteristics of headache

\begin{tabular}{lc}
\hline Characteristics of headache & N (\%) \\
\hline Family history $(+)$ & $44(55,0)$ \\
Location of headache & \\
Global & $29(37,2)$ \\
Frontal & $28(35,9)$ \\
Temporal & $11(14,1)$ \\
Occipital & $10(12,8)$ \\
Frequency of headache & \\
<3/weeks & $46(60,5)$ \\
$>$ 3/weeks & $30(39,5)$ \\
Duration of the attack: & \\
1 hour and below & $19(25,3)$ \\
2-4 hours & $36(48)$ \\
5-7 hours & $9(12)$ \\
8-12 hours & $7(9,3)$ \\
Over12 hours & $4(5,3)$ \\
\hline
\end{tabular}

The most common consequences identified consequences and symptoms accompanying headaches were limited life accompanying the headaches are detailed in activities $(58 \%)$ and symptoms such as nausea (34\%) and visual impairment (18.8\%). All Table 3.

Table 3. Symptoms accompanying headache

\begin{tabular}{lc}
\hline $\begin{array}{l}\text { Symptoms accompanying } \\
\text { headache }\end{array}$ & $\mathbf{N}(\%)$ \\
\hline Limited life activities $(+)$ & $58(72,5)$ \\
Nausea $(+)$ & $34(42,5)$ \\
Visual Impairment $(+)$ & $15(18,8)$ \\
Vomit (+) & $11(13,8)$ \\
Abdominal pain $(+)$ & $6(7,5)$ \\
Fever $(+)$ & $5(6,3)$ \\
\hline
\end{tabular}




\section{Inter-group analyses}

In the headache group, behavioral control $(p=0.020)$, general functions $(p=0.034)$ and total score of FAS $(\mathrm{p}=0.046)$ were higher than the control group. However, STAI I $(\mathrm{p}=0.509)$ and II $(\mathrm{p}=0.542)$, problem solving $(\mathrm{p}=0.168)$, communication $(\mathrm{p}=0.520)$, roles $(\mathrm{p}=0.082)$, emotional reaction $(\mathrm{p}=0.654)$, showing required attention $(\mathrm{p}=0.943)$ scores of FAS were similar between groups (Table 4).

Table 4. The relationship between STAI and Family Assessment Form between groups

\begin{tabular}{lccccc}
\hline & & $\begin{array}{c}\text { Headache } \\
(\mathbf{n = 8 0})\end{array}$ & $\begin{array}{c}\text { Control } \\
(\mathbf{n = 7 4 )}\end{array}$ & Test & $\mathbf{P}$ \\
\hline STAI & I & $37,4 \pm 9,6$ & $38,4 \pm 9,1$ & $t=0,662$ & 0,509 \\
\hline \multirow{2}{*}{ FamilyAssessment Scale } & II & $42,5 \pm 9,3$ & $43,3 \pm 7,7$ & $t=0,610$ & 0,542 \\
& Total score & $14,1 \pm 2,5$ & $13,3 \pm 2,0$ & $t=2,011$ & $\mathbf{0 , 0 4 6}$ \\
& Problem solving & $1,4 \pm 2,5$ & $1,8 \pm 0,6$ & $t=1,385$ & 0,168 \\
& Communication & $1,9 \pm 0,5$ & $1,8 \pm 0,4$ & $t=1,957$ & 0,520 \\
& Roles & $2,0 \pm 0,4$ & $1,9 \pm 0,3$ & $t=1,748$ & 0,082 \\
& Emotional reaction & $1,8 \pm 0,6$ & $1,8 \pm 0,5$ & $t=0,454$ & 0,654 \\
& Showing required attention & $2,2 \pm 0,4$ & $2,2 \pm 0,3$ & $t=0,072$ & 0,943 \\
& Behavior control & $2,0 \pm 0,3$ & $1,9 \pm 0,3$ & $\boldsymbol{t}=2,344$ & $\mathbf{0 , 0 2 0}$ \\
& & & & & \\
& General functions & $1,8 \pm 0,5$ & $1,6 \pm 0,4$ & $\boldsymbol{t}=\mathbf{2 , 1 4 6}$ & $\mathbf{0 , 0 3 4}$ \\
\hline
\end{tabular}

\section{Discussion}

Headaches can commonly occur for reasons such as hunger or fatigue, but they are rarely associated with life-threatening secondary causes such as brain tumors (10). Migraine and tension headaches are the common types of primary headaches experienced in childhood. In Turkey, migraine and tension headaches have been reported to occur at a frequency of approximately $7 \%$ in school-age children (11). Common headaches in school age children worry parents.

To date, many features of headaches have been evaluated. Through the analysis of twin studies, genetic causes have been found to be responsible for headaches at the rate of 40 $60 \%$, while environmental factors have also been noted to be important reasons for headaches $(12,13)$. Nevertheless, despite the detailing of many environmental factors, the impact of the parent's psychosocial characteristics, family characteristics, and potential factors related to the family's attitude on childhood headaches have only been the subject of a limited number of studies.
Our findings established that FAS had only been used to evaluate the familial functionality of a limited number of families with children with headaches. Moreover, families were also found to be less successful in particular aspects but especially in the field of behavior control and general functions. Our findings indicated that familial functionality or parenting behaviors may have an impact on childhood headaches. However, following the assessment of the trait and anxiety states using the STAI, no significant differences were identified between the families of children with and without headaches.

Social learning studies have indicated that familial models impact the way children perceive and express their physical symptoms (14). Accordingly, associations were proposed between familial factors such as parental behavior and familial functionality and children's physical health problems. Various studies report that familial factors do have an effect on children's health, and specifically on headaches. The findings of these studies support our findings. Ertem et al. (15) observed that the authoritarian-repressive 
behavior pattern was more common in mothers of children with pre-adolescent migraine. These findings correspond to the inadequate control of family behaviors in the parents of children with headaches in our study. Similarly, Kaczynski et al. (16) observed that both the mother's and the father's characteristics had an impact on primary headaches experienced in childhood. Moreover, Palermo et al. (17) reported that familial conflicts were more common among adolescents with chronic headaches. Furthermore, a study by Esposito et al. (18) reported a difference in the personality characteristics of children with migraines compared to the controls. Studies have noted that in families of children who experience recurrent headaches and abdominal pain, domestic problems, marital problems, divorce, and child abuse are more common (19-21). The current findings further affirm that familial, domestic, or parent-related factors do have an impact on childhood headaches. Therefore, the successful management of childhood headaches can be enhanced through the treatment of negative factors in the family and in ensuring effective parenting.

Conversely, unlike our findings regarding family functionality and parental characteristics, many studies have established that psychiatric comorbidities observed in parents have an impact on childhood primary headache syndromes. Galli et al. (22) demonstrated that psychiatric comorbidities were more common in families of children with migraines, in a study in which 200 children with headaches and their families were questioned. Similarly, Merikangas et al. (23) stated that psychiatric diseases such as anxiety and mood disorders are more frequent in families of children with migraines. Additionally, Esposito et al. (27) reported higher stress levels using the "Parent Stress Index" in mothers of children with migraines compared to the control group. In contrast to these studies, the findings of our study indicated no differences between the anxiety levels in families of children with headaches and those without headaches. The evaluation of children with headaches for the first time rather than primary headache syndromes may be an important reason why such a relationship could not be indicated in our study. Instead of familial psychiatric comorbidities, it can be claimed that the family's functionality and attitude towards the child are effective causes of headaches. Nonetheless, childhood headaches can be attributed to many factors. Therefore, more comprehensive outcomes can be obtained through prospective studies evaluating the effect of treating familial comorbidities on headaches in children.

Furthermore, our findings also indicated that headaches were experienced by the parents of approximately half of the children with headaches, thereby further indicating the contribution of the familial burden. There is a large body of evidence concerning the presence of this familial burden and/or familial transition in childhood primary headaches $(22,25)$. Likewise, many studies also support our findings that headaches are more common in girls and in children with lower levels of family education and a lower economic level (26-30).

Our study had some limitations. First, our study did not employ a cause-effect study design, thus such an association could not be examined. Second, the evaluation of patients with headache symptoms rather than patients with primary headache syndromes may have caused the examination of a heterogeneous group.

In conclusion, our findings indicate that family characteristics and familial functionality rather than parental anxiety are among the factors that can lead to childhood headaches. Therefore, children with headaches should be evaluated together with familial factors in addition to physical examinations, laboratory, and imaging studies.

\section{Ethics Approval}

The study was approved by the local ethics committee (approval no: 2019-101).

\section{Acknowledgement}

The authors gratefully acknowledge Scribendi (www.scribendi.com) for English language editing. 


\section{REFERENCES}

1. Wöber-Bingöl C. Epidemiology of migraine and headache in children and adolescents. Curr Pain Headache Rep. 2013;17:341.

2. Yilmaz D, Gökkurt D, Tayfur A. Evaluation of Childhood Headache in an Outpatient Pediatric Neurology Clinic. Turkish Journal of Pediatric Disease. 2016:10:162-65.

3. Holden EW, Gladstein J, Trulsen M, et al. Chronic daily headache in children and adolescents. Headache. 1994;34:508-14.

4. Fearon P, Hotopf M. Relation between headache in childhood and physical and psychiatric symptoms in adulthood: National birth cohort study. BMJ. 2001;322:1145.

5. Guidetti V, Galli F, Fabrizi P, et al. Headache and psychiatric comorbidity: Clinical aspects and outcome in an 8-year follow-up study. Cephalalgia. 1998;18:455-62.

6. Spielberger, C.D., R.C. Gorsuch, and R.E. Luschene. Manual for the State-Trait Anxiety invenntory. California: Consulting Psychologists Press; 1970.

7. Öner, N. and A. Le Compte. Durumluk Sürekli Kayg1 Envanteri El Kitab1 (in Turkish). İstanbul: Boğaziçi Üniversitesi Yayını; 1983.

8. Epstein NB, Baldwin LM, Bishop DS. The McMaster Family Assessment Device. $J$ Marital Fam Ther. 1983;9:171-80.

9. Bulut, I. Aile değerlendirme ölçeği el kitabı (in Turkish). Ankara: Özgüzeliş Matbaası; 1990.

10. How $\mathrm{CH}$, Chan WS. Headaches in children. Singapore Med J. 2014;55:128-31.

11. Poyrazoğlu HG, Kumandas S, Canpolat M, et al. The prevalence of migraine and tensiontype headache among schoolchildren in Kayseri, Turkey: an evaluation of sensitivity and specificity using multivariate analysis. $J$ Child Neurol. 2015;30:889-95.

12. Larsson B, Bille B, Pedersen NL. Genetic influences in headache: a Swedish twin study. Headache. 1995;35:513-519.

13. Ziegler DK, Hur YM, Bouchard TJ Jr, et al. Migraine in twins raised together and apart. Headache. 1998;38:417-422.

14. Bandura A. Self-efficacy: toward a unifying theory of behavioral change. Psychol Rev. 1977;84:191-215.

15. Ertem DH, Bingol A, Ugurcan B, et al. The impact of parental attitudes toward children with primary headaches. Clin Child Psychol Psychiatry. 2019;24:767-75.

16. Kaczynski KJ, Claar RL, Lebel AA. Relations between pain characteristics, child and parent variables, and school functioning in adolescents with chronic headache: A comparison of tension-type headache and migraine. Journal of Pediatric Psychology. 2013;38:351-64.

17. Palermo TM, Valrie CR, Karlson CW. Family and parent influences on pediatric chronic pain: a developmental perspective. $A m$ Psychol. 2014;69:142-52.

18. Esposito M, Roccella M, Gallai B, et al. Maternal personality profile of children affected by migraine. Neuropsychiatr Dis Treat. 2013;9:1351-58.

19. Anttila P, Sourander A, Metsähonkala L, et al. Psychiatric symptoms in children with primary headache. $J$ Am Acad Child Adolesc Psychiatry. 2004;43:412-19.

20. Emiroglu FN, Kurul S, Akay A, et al. Assessment of child neurology outpatients with headache, dizziness and fainting. $J$ Child Neurol. 2004;19: 332-36.

21. Zuckerman B, Stevenson J, Bailey V. Stomachaches and headaches in a community sample of preschool children. Pediatrics. 1987;79:677-682.

22. Galli F, Canzano L, Scalisi TG, et al. Psychiatric disorders and headache familial recurrence: a study on 200 children and their parents. J Headache Pain. 2009;10:187-97.

23. Merikangas KR, Merikangas JR, Angst J. Headache syndromes and psychiatric disorders: association and familial transmission. J Psychiatr Res. 1993;27:197210.

24. Esposito M, Gallai B, Parisi L, et al. Maternal stress and childhood migraine: a new perspective on management. Neuropsychiatr Dis Treat. 2013;9:351-55.

25. Ostergaard S, Russell MB, Bendsten L, et al. Comparison of first-degree relatives and spouses of people withchronic tension-type headache. BMJ. 1997;3:1092-93.

26. Abu-Arefeh I, Russell G. Prevalence of headache and migraine in schoolchildren. BMJ. 1994;309:765-69.

27. Kroner-Herwig B, Heinrich M, Morris L. Headache in German children and adolescents:A populationbased epidemiological study. Cephalalgia. 2007;27:519-27.

28. Anttila P, Sourander A, Metsahonkala L et al. Psychiatric symptoms in children with primary headache. $J$ Am Acad Child Adolesc Psychiatry. 2004;43:412-19.

29. Işik U, Topuzoğlu $A$, Ay $P$, et al. The prevalence of headache and its association with socioeconomic status among school children in Istanbul, Turkey. Headache. 2009;49:697-703.

30. Ostberg V, Alfven G, Hjern A. Living conditions and psychosomatic complaints in Swedish school children. Acta Paediatr. 2006;95:929-34. 